\title{
FGFR4 GLY388ARG polymorphism modulates cancer patients' survival in pooled analysis
}

\author{
Elisa Frullanti ${ }^{*}$,Tommaso A Dragani \\ From 16th International Charles Heidelberger Symposium on Cancer Research \\ Coimbra, Portugal. 26-28 September 2010
}

Several studies support the hypothesis that patients' prognosis and survival may be modulated not only by somatic alterations, but also by constitutive genetic factors. Among the few germline variations that have been associated with survival and/or clinical prognostic parameters of cancer patients is the Gly388Arg polymorphism (rs351855) of the fibroblast growth factor receptor 4 (FGFR4) that showed contrasting results in different association studies. Here, we assessed the association between the FGFR4 Gly388Arg polymorphism and cancer prognosis carrying out a meta- and pooled analyses of 6,028 and 2,537 cancer cases, respectively, by nodal status, clinical stage, and overall survival. A statistically significant association between FGFR4 Arg388Arg homozygosity and nodal status was found in the metaanalysis but not in the pooled analysis adjusted for confounding factors. In the pooled analysis, Gly388Arg heterozygous carriers showed an increased hazard of poor overall survival as compared to homozygous carriers of the common Gly388 allele, even after adjusting for clinical stage or nodal status $(\mathrm{HR}=1.24,95 \% \mathrm{CI}$ $1.06-1.45)$. These results provide evidence of a role for the FGFR4 Gly388Arg polymorphism in modulating patients' outcome in different types of cancer. The tight linkage disequilibrium of the polymorphism with missense and intronic single nucleotide polymorphisms of the FGFR4 locus might explain the contradictory associations of this polymorphism with patient outcome reported thus far.

Published: 24 September 2010

\footnotetext{
* Correspondence: elisa.frullanti@istitutotumori.mi.it

Department of Predictive and for Prevention Medicine, Fondazione IRCCS,

Istituto Nazionale Tumori, Milan, Italy

Full list of author information is available at the end of the article
}

doi:

Cite this article as: Frullanti and Dragani: FGFR4 GLY388ARG

polymorphism modulates cancer patients' survival in pooled analysis. BMC Proceedings 2010 4(Suppl 2):P56.
Submit your next manuscript to BioMed Central and take full advantage of:

- Convenient online submission

- Thorough peer review

- No space constraints or color figure charges

- Immediate publication on acceptance

- Inclusion in PubMed, CAS, Scopus and Google Scholar

- Research which is freely available for redistribution

Submit your manuscript at www biomedcentral com/submit
C Biomed Central 